\title{
Klasifikasi impaksi caninus rahang atas pada pemeriksaan radiograf panoramik dan CBCT sebagai penunjang odontomy
}

\author{
Ika Rachmawati ${ }^{*}$, Ria Noerianingsih Firman²
}

\begin{abstract}
Objectives: To assess the difficulty level of dental the palatal region with a horizontal position impaction treatment. This article discusses the according to the maxillary sinus and nasal cavity so problem of odontomy treatment based on the that complications are required during odontomy. classification of maxillary canine impaction through panoramic radiograph examination and $C B C T$.

Conclusion: Based on this literature study, classification on impacted maxillary canine teeth Literature Review: Impacted tooth is pathological has been developed based on panoramic (2D) and where the tooth fails to reach its normal functional CBCT (3D) radiography, so thus resulting in a position. Impaired maxillary canine second order complete classification of impacted maxillary canine placement after impact of third molars. The location teeth and can be used as a predictor of the difficulty of impacted jaw canine teeth most often occurs in level of maxillary canine tooth impaction treatment.

Keywords: maxillary canine impaction, classification, odontomy, panoramic radiograph, CBCT

Cite this article: Rachmawati I, Firman RN. Klasifikasi impaksi caninus rahang atas pada pemeriksaan radiograf panoramik dan CBCT sebagai penunjang odontomy. Jurnal Radiologi Dentomaksilofasial Indonesia 2020;4(2)35-42. https:// doi.org/10.32793/jrdi.v4i2.532
\end{abstract}

${ }^{1}$ PPDGS Radiologi Kedokteran Gigi, Fakultas Kedokteran Gigi, Universitas Padjadjaran, Bandung, Indonesia 40132

${ }^{2}$ Departemen Radiologi Kedokteran Gigi, Fakultas Kedokteran Gigi, Univer sitas Padjadjaran, Bandung, Indonesia, 40132

${ }^{*}$ Correspondence to:

Ika Rachmawati

囚ika19002@mail.unpad.ac.id

Received on: June 2020

Revised on: July 2020

Accepted on: August 2020

\section{PENDAHULUAN}

Impaksi gigi kaninus rahang atas merupakan masalah perkembangan gigi yang secara signifikan mempengaruhi $1-3 \%$ dari populasi. Impaksi gigi kaninus rahang atas menempati urutan ketiga setelah impaksi gigi molar tiga rahang bawah dan gigi molar tiga rahang atas. Prevalensi impaksi gigi kaninus rahang atas dalam kisaran 0.9\% - 3.0\%, tergantung pada populasi yang diperiksa. Impaksi gigi kaninus rahang atas paling sering ditemukan pada perempuan dibandingkan pada laki-laki. Insidensi impaksi kaninus rahang atas dua kali lipat lebih banyak dibandingkan dengan rahang bawah. ${ }^{1,2,11}$

Faktor etiologi impaksi gigi kaninus dapat bersifat lokal, sistemik atau genetik. Faktor lokal yang paling umum adalah perbedaan ukuran gigi dengan panjang lengkung gigi, kegagalan resorpsi akar gigi kaninus desidui, prolong retensi gigi desidui, ankilosis gigi kaninus, terdapat kista atau neoplasma, dilaserasi akar, kehilangan gigi incisivus lateralis, variasi ukuran akar gigi incisivus lateralis, faktor iatrogenik dan faktor idiopatik. Faktor sistemik penyebab impaksi gigi kaninus adalah adanya defisiensi endokrin dan iradiasi. Faktor genetik penyebab impaksi gigi kaninus adalah faktor keturunan dan adanya celah pada palatum. ${ }^{11,12}$

Kesulitan dalam perawatan impaksi gigi kaninus rahang atas membutuhkan pemeriksaan yang komprehensif. Metode pemeriksaan yang dapat digunakan untuk membantu diagnosis gigi impaksi adalah radiograf panoramik dan CBCT. Radiograf panoramik (2D) merupakan modalitas yang paling umum digunakan secara klinis sebagai radiografi diagnostik utama untuk menentukan lokasi impaksi gigi kaninus rahang atas, menetukan recana perawatan dan evaluasi hasil perawatan. Validitas dan keakuratan dari radiograf panoramik (2D) sangat lemah, hal ini disebabkan karena kesalahan proyeksi distorsi dan dapat mengakibatkan dalam salah penafsiran. ${ }^{4,12,13,15}$

Perencanaan perawatan impaksi gigi kaninus membutuhkan diagnosis yang tepat sehingga memerlukan radiograf (3D) CBCT karena dapat mengatasi keterbatasan radiograf konvesional. Penentuan posisi impaksi gigi kaninus rahang atas yang dimasukkan dalam klasifikasi dapat membantu secara cepat dan tepat dalam penentuan tingkat kesulitan perawatan impaksi gigi kaninus rahang atas, sehingga berdampak dalam penentuan strategi perawatan yang tepat. ${ }^{3,4}$

Impaksi gigi kaninus rahang atas dari pengamatan radiograf panoramik (2D) diklasifikasikan menjadi klasifikasi Archer yaitu berdasarkan posisi impaksi gigi kaninus rahang atas dan klasifikasi Yamamato berdasarkan orientasi long axis gigi kaninus rahang atas terhadap bidang oklusal. Impaksi gigi kaninus rahang atas dari pengamatan radiograf CBCT (3D) diklasifikasikan menjadi klasifikasi Ghoneima yaitu berdasarkan 
posisi dan lokasi impaksi gigi dan indeks KPG berdasarkan jumlah skor nilai dari sumbu $\mathrm{x}$, sumbu y, dan sumbu z. .,10,21 $^{2}$

Perawatan impaksi gigi kaninus rahang atas yang mengakibatkan gangguan terhadap jaringan sekitar dapat dilakukan dengan tindakan bedah odontomy. Odontomy adalah teknik bedah dengan cara mengeluarkan gigi yang mengalami impaksi dari rahang. ${ }^{17}$

\section{STUDI PUSTAKA}

Perawatan impaksi gigi kaninus dilakukan dengan prosedur bedah sehingga membutuhkan pendekatan interdisipliner. Prognosis keberhasilan perawatan impaksi gigi kaninus dapat dilakukan dengan cara penentuan posisi dan lokasi impaksi gigi kaninus melalui pemeriksaan radiograf panoramik (2D) dan radiograf CBCT (3D) untuk memperoleh informasi mengenai detail tulang dan struktur gigi. ${ }^{3}$

Archer pada tahun 1965 mendefinisikan impaksi gigi kaninus sebagai suatu keadaan gigi terhalang untuk erupsi. Impaksi gigi kaninus rahang atas diklasifikasikan sebagai berikut yaitu, Kelas I yaitu posisi impaksi gigi kaninus terletak di palatal dengan posisi horizontal atau vertikal. Kelas II yaitu impaksi gigi kaninus terletak di permukaan labial atau bukal dengan posisi horizontal atau vertikal. Kelas III yaitu impaksi gigi kaninus terletak di processus palatal dan labial rahang atas dengan posisi mahkota gigi terletak di akar palatal dan melintas di antara gigi tetangga kemudian berakhir pada permukaan labial atau bukal rahang atas atau sebaliknya mahkota berada di bukal dan akar berada di palatal. Kelas IV yaitu impaksi gigi kaninus terletak di processus alveolaris. Kelas $\mathrm{V}$ yaitu impaksi gigi kaninus terletak pada rahang yang tidak bergigi. ${ }^{17}$

Yamammato pada tahun 2003 mengajukan klasifikasi impaksi gigi kaninus rahang atas berdasarkan orientasi long axis gigi kaninus rahang atas terhadap bidang oklusal menjadi tujuh tipe (Gambar 1). Tipe I yaitu posisi impaksi gigi kaninus rahang atas vertikal, hampir tegak lurus terhadap sumbu gigi, terletak di antara gigi incisivus lateralis dan gigi premolar pertama rahang atas. Tipe II yaitu posisi mahkota lebih condong ke arah mesial terhadap bidang oklusal. Tipe III yaitu posis mahkota lebih condong ke arah distal terhadap bidang oklusal. Tipe IV yaitu posisi impaksi gigi kaninus horizontal dengan mahkota berada di mesial. Tipe $V$ yaitu posisi impaksi gigi kaninus horizontal dengan mahkota berada di distal. Tipe VI yaitu posisi mahkota gigi kaninus menghadap ke arah fossa orbita. Tipe VII yaitu posisi impaksi gigi kaninus labio-palatal (ektopik) dengan posisi mahkota berada di bukal. ${ }^{22}$

Ghoneima pada tahun 2014 mengajukan klasifikasi impaksi kaninus rahang atas berdasarkan posisi dan lokasi menjadi sepuluh tipe (Gambar 2 dan 3). Tipe A yaitu impaksi gigi kaninus dalam posisi mesioangular di sebelah posterior apikal gigi incisivus sentralis. Tipe B yaitu impaksi gigi kaninus dalam posisi vertikal terletak pada posterior apikal gigi incisivus lateralis. Tipe $C$ yatu impaksi gigi kaninus dalam posisi vertikal diantara gigi incisivus lateralis dan premolar pertama rahang atas. Tipe D yaitu impaksi gigi kaninus dalam posisi vertikal terletak di antara gigi premolar pertama dan premolar kedua rahang atas. Tipe E yaitu impaksi

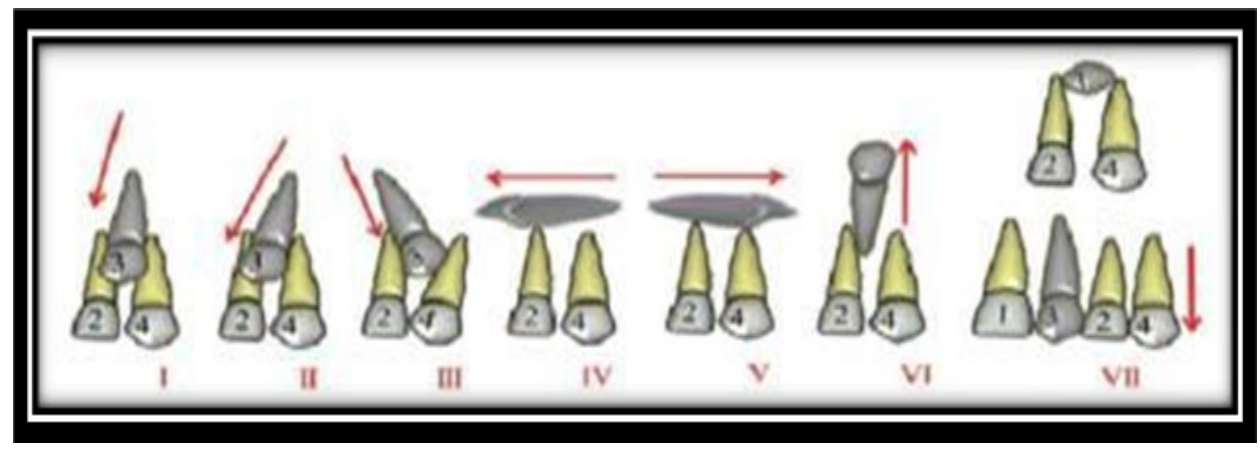

Gambar 1. Klasifikasi impaksi gigi kaninus rahang menurut Yamamato atas berdasarkan orientasi long aksis gigi kaninus rahang atas terhadap bidang oklusal ${ }^{22}$

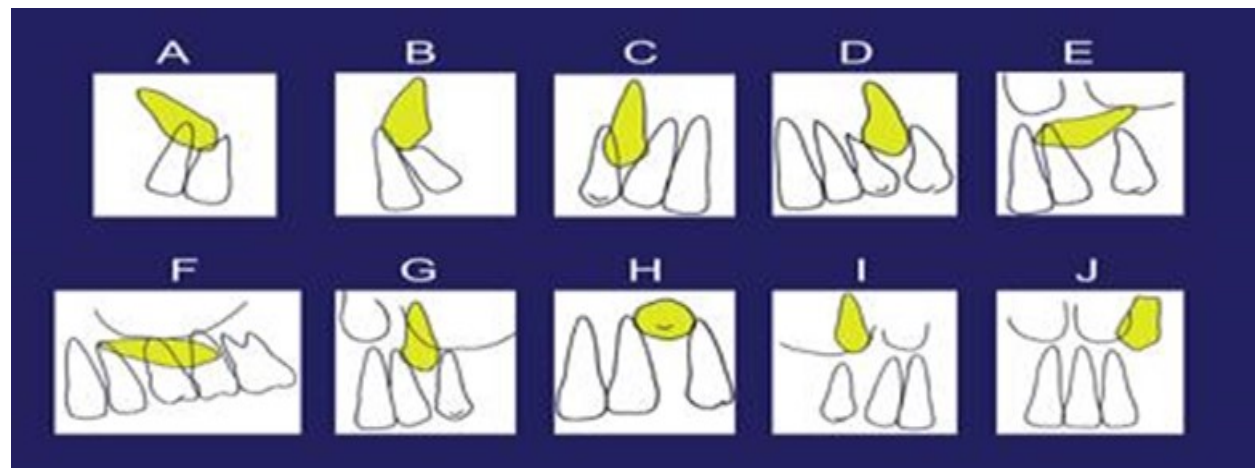

Gambar 2. Klasifikasi impaksi kaninus rahang atas menurut Ghoneima $2014^{9}$ 

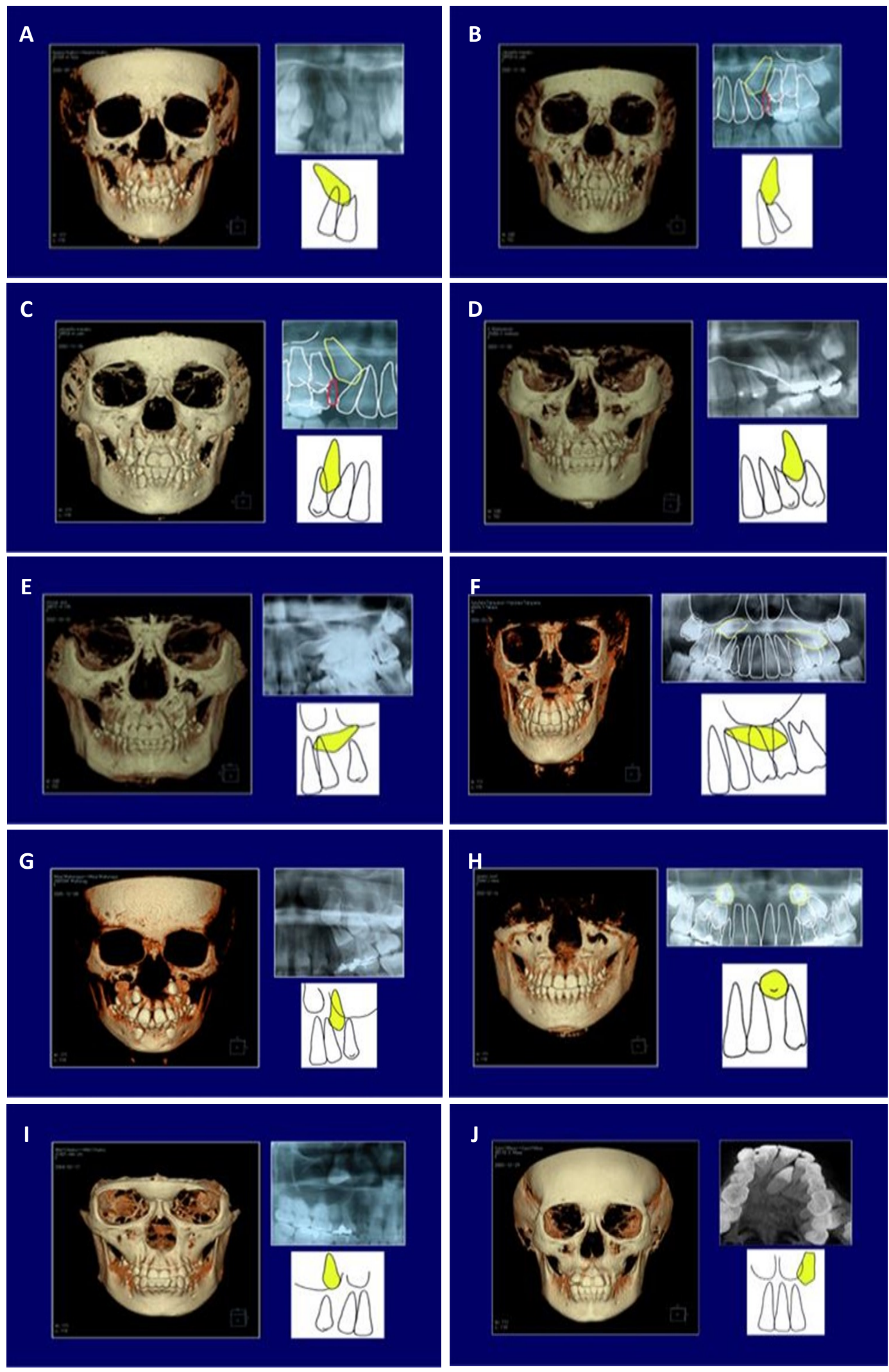

Gambar 3. Klasifikasi impaksi kaninus rahang atas menurut Ghoneima yang dibagi menjadi 10 macam dari A hingga J ${ }^{9}$

gigi kaninus dalam posisi mesioangular dan terletak di antara dinding anterior - inferior dari sinus maksilaris dan bagian basilar dari ronnga hidung. Tipe $F$ yaitu impaksi gigi kaninus dalam posisi horizontal dekat dengan dinding inferior sinus maksilaris dengan posisi mahkota diantara gigi incisivus lateralis dan premolar pertama. Tipe $G$ yaitu impaksi gigi kaninus dalam posisi vertikal dengan akar masuk dalam sinus maksilaris. Tipe $\mathrm{H}$ yaitu impaksi gigi kaninus dalam posisi horizontal, dekat dengan dinding inferior sinus maksila dengan mahkota terletak pada bukal atau diantara gigi incisivus lateral dan premolar pertama. Tipe I yaitu impaksi gigi kaninus dengan seluruh bagian gigi 
berada di dalam sinus maksilaris. Tipe J yaitu impaksi gigi kaninus berada di palatal. ${ }^{9}$

Klasifikasi indeks KPG (Kou, Pann dan Gallerano) menggunakan skala seperti grid dibuat dari tiga tampilan radiograf yang berbeda $(x, y, z)$. Klasifikasi indeks KPG tergantung pada lokasi anatomis, ujung puncak, ujung akar dan setiap gambar radiograf masing-masing diberi nomor pada skala 0-5. Jumlah dari ujung cusp dan ujung akar dalam tiga tampilan yang berbeda akan membantu dalam memutuskan perawatan yang sesuai,dan diklasifikasikan menjadi empat kategori yaitu mudah, sedang, sulit dan sangat sulit. ${ }^{14,15,16}$

Sumbu $X$ digunakan sebagai pedoman dalam menentukan posisi kaninus (Gambar 4). Klasifikasi sumbu $X$ sebagai berikut, nilai 0 yaitu ujung cusp atau ujung akar berada pada lokasi erupsi yang tepat sehingga tidak diperlukan perawatan dalam dimensi ini. Nilai 1 yaitu ujung cusp atau ujung akar berada dalam alveolus dan kedua sisi garis vertikal membagi dua kaninus. Nilai 2 yaitu ujung cusp atau ujung akar berada di area tepi alveolus dan garis vertikal membagi dua gigi yang berdekatan (setengah bagian lateral gigi incisivus atau setengah mesial dari premolar pertama. Nilai 3 yaitu ujung cusp atau ujung akar berada di ujung gigi sebelahnya (setengah dari gigi incisivus lateralis atau setengah dari premolar pertama). Nilai 4 yaitu ujung cusp atau ujung akar berada di setengah bagian gigi incisivus atau berada di distal premolar pertama tetapi lebih ke mesial dari garis tengah premolar ke dua. Nilai 5 yaitu ujung cusp atau ujung akar berada di bagian tengah mesial gigi incisivus atau distal ke garis tengah premolar kedua. ${ }^{16}$

Klasifikasi sumbu Y (Gambar 5) sebagai berikut, nilai 0 yaitu ujung cusp gigi kaninus berada di lokasi vertikal yang tepat. Nilai 1 yaitu Ujung cusp berada di wilayah koronal. Nilai 2 yaitu ujung cusp terletak pada bidang horizontal dengan bagian servikal berada di sepertiga akar gigi incisivus lateralis. Nilai 3 yaitu ujung cusp terletak pada bidang horizontal dengan bagian tengah terletak pada sepertiga akar gigi incisivus lateralis. Nilai 4 yaitu ujung cusp terletak pada bidang horizontal dengan sepertiga apical dari akar gigi seri. Nilai 5 ujung cusp lebih supraapikal ke akar gigi incisivus lateralis. ${ }^{15,16}$

Ujung akar dan ujung cusp berada pada ujung yang berlawanan dari gigi, skala untuk lokasi ujung akar adalah hampir berlawanan dengan ujung puncak (Gambar 6). Nilai 0 ujung akar kaninus berada di lokasi vertikal yang tepat. Nilai 1 yaitu Ujung akar terletak pada bidang horizontal yaitu pada sepertiga apikal akar gigi incisivus lateralis. Nilai 2 yaitu ujung akar terletak pada bidang horizontal yaitu pada sepertiga tengah dari akar gigi incisivus lateralis. Nilai 3 yaitu ujung akar terletak pada bidang horizontal dengan bagian servikal pada sepertiga akar gigi incisivus lateralis. Nilai 4 yaitu ujung akar berada di daerah koronal. Nilai 5 yaitu ujung akar memanjang melewati daerah koronal. ${ }^{16}$

Klasifikasi sumbu Z untuk menentukan posisi impaksi gigi kaninus dengan menggunakan tampilan aksial pada CBCT. Skala ini menggunakan jarak diukur secara tegak lurus dalam kenaikan 2

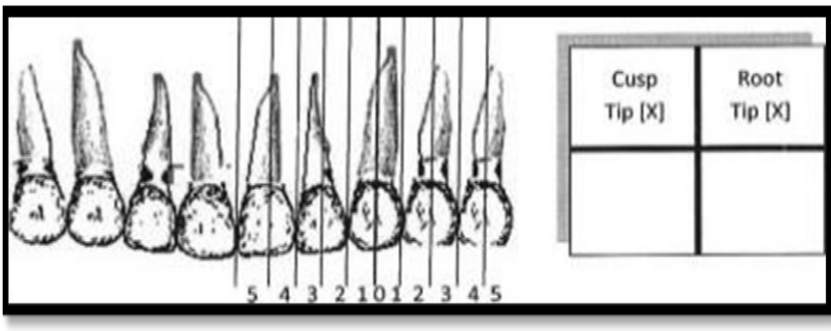

Gambar 4. Indeks KPG dimensi anterior-posterio (X) untuk ujung cusp dan ujung akar, tampilan frontal $^{16}$
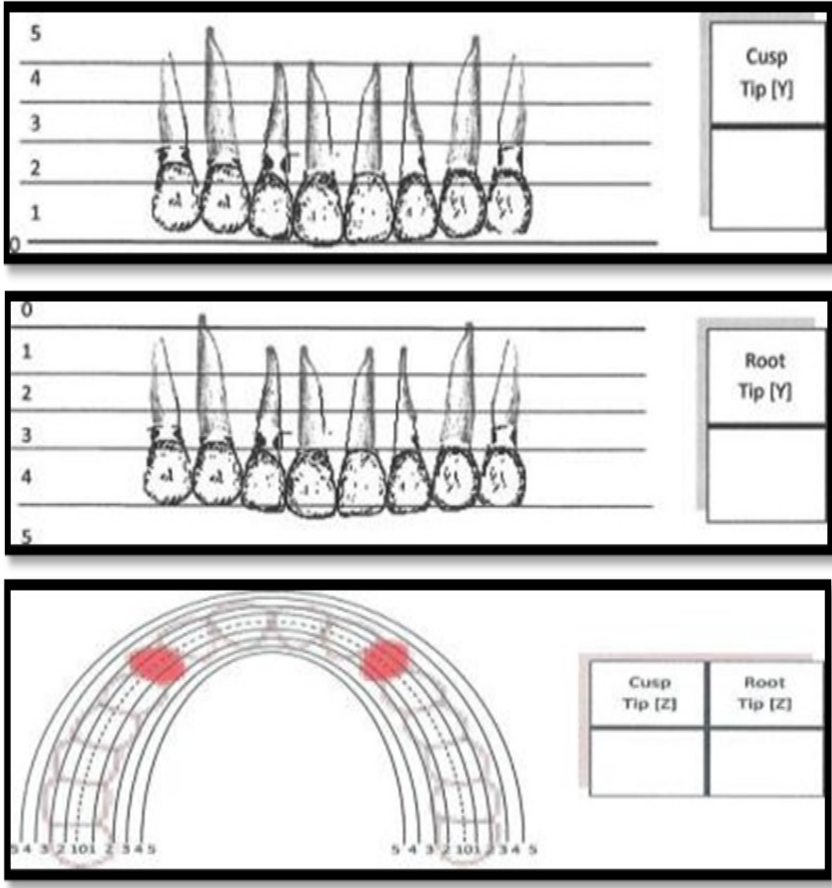

Gambar 5. Indeks KPG dimensi vertikal (Y) untuk ujung cusp, tampilan frontal ${ }^{16}$

Gambar 6. Indeks KPG dimensi vertikal (Y) untuk ujung akar, tampilan frontal ${ }^{16}$

Gambar 7. Indeks KPG dimensi oklusal (Z), tampilan aksial ${ }^{16}$ 

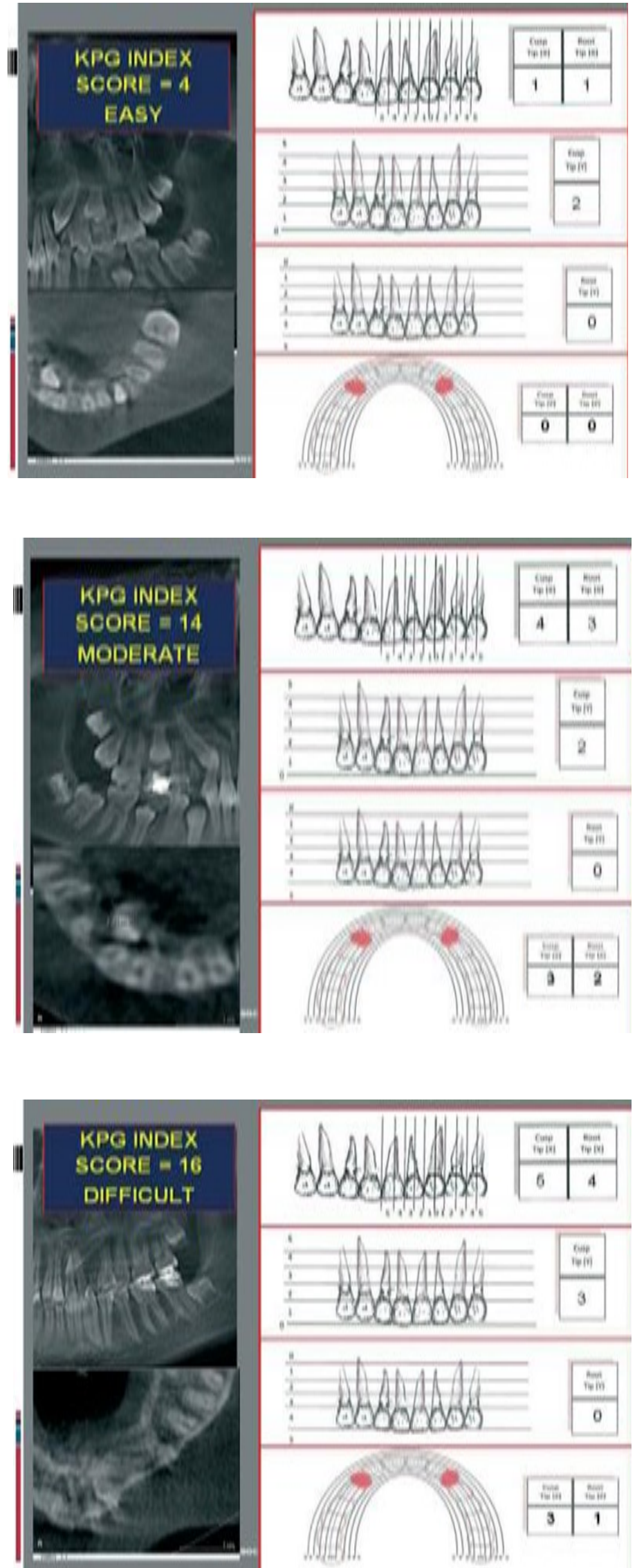

Gambar 8. Contoh evaluasi impaksi gigi kaninus berdasarkan KPG indeks dengan hasil mudah untuk dilakukan perawatan ${ }^{16}$
Gambar 9. Contoh evaluasi impaksi gigi kaninus berdasarkan KPG indeks dengan hasil moderat untuk dilakukan perawatan ${ }^{16}$
Gambar 10. Contoh evaluasi impaksi gigi kaninus berdasarkan KPG indeks dengan hasil sulit untuk dilakukan perawatan ${ }^{16}$ $\mathrm{mm}$ dari puncak atau ujung akar ke garis lengkung oklusal. Pembagian skala 0-5 didasarkan pada jarak ujung impaksi ke referensi lengkung oklusal. Skala pengukuran ini berbeda dari dua tampilan sumbu $X$ dan sumbu $\mathrm{Y}$, yang didasarkan dengan lokasi anatomi (Gambar 7). Nilai 0 yaitu ujung cusp atau ujung akar gigi kaninus berada di lokasi yang tepat di sepanjang lengkung oklusal. Nilai 1 yaitu ujung 
cusp atau ujung akar gigi kaninus berada $0-2.0 \mathrm{~mm}$ dari lengkung oklusal. Nilai 2 yaitu ujung cusp atau ujung akar gigi kaninus berada terletak di area berjarak 2,0-4,0 $\mathrm{mm}$ dari lengkung oklusal, baik secara bukal atau lingual. Nilai 3 yaitu ujung cusp atau ujung akar gigi kaninus berada di area 4.0-6.0 $\mathrm{mm}$ dari lengkung oklusal, baik secara bukal atau lingual. Nilai 4 yaitu ujung cusp atau ujung akar gigi kaninus berada terletak di area $6.0-8.0 \mathrm{~mm}$ dari lengkung oklusal, baik secara bukal atau lingual. Nilai 5 yaitu ujung cusp atau ujung akar gigi kaninus berada lebih dari $8,0 \mathrm{~mm}$ dari lengkung oklusal normal, baik secara bukal maupun lingual. ${ }^{16}$

Klasifikasi indeks KPG merupakan klasifikasi impaksi gigi kaninus rahang atas yang didapatkan berdasarakan jumlah dari semua skor $X$, skor $Y$, dan skor Z. Skor dalam kisaran 0-9 termasuk dalam kategori mudah (Gambar 8), skor 10-14 moderat (Gambar 9), skor 15-19 sulit (Gambar 10), dan skor di atas 20 sangat sulit. ${ }^{16}$

\section{DISKUSI}

Impaksi gigi kaninus rahang atas diakibatkan oleh kurangnya ruang untuk erupsi. Gigi kaninus rahang atas pertama kali terbentuk pada usia kehamilan 24 minggu dan tertanam dalam rahang atas kurang lebih selama 12 tahun, oleh karena itu erupsi gigi kaninus lebih lambat dibandingan dengan erupsi gigi lainnya. Erupsi gigi kaninus dipengaruhi oleh gigi incisivus lateralis, karena gigi incisivus lateralis merupakan pemandu erupsi gigi kaninus rahang atas. ${ }^{11,18}$

Perawatan impaksi gigi kaninus rahang atas sering mengalami kesulitan. Perawatan impaksi gigi kaninus rahang atas memerlukan manajemen terapi komprehensif. Metode estimasi tingkat kesulitan perawatan impaksi gigi kaninus rahang atas yang berkembang pada saat ini didominasi hasil interpretasi radiograf. ${ }^{6,7}$

Radiograf dua dimensi seperti periapikal, oklusal, panoramik, dan sefalometri dianggap sebagai alat standar untuk diagnosis pra-operasi. Pada sebagian besar kasus, keakuratan dan validitas untuk klasifikasi impaksi gigi kaninus dengan struktur anatomis yang berdekatan sangat terbatas dan mengakibatkan salah tafsir akibat dari superimposisi dan kesalahan proyeksi distorsi. Studi pustaka ini membahas peranan dari radiograf panoramik dan CBCT untuk memastikan keakuratan lokalisasi dari impaksi gigi kaninus dan evaluasi secara tepat dari resorpsi gigi incisivus dan hubungan dengan struktur tulang. ${ }^{8}$

Metode estimasi tingkat kesulitan pembedahan yang berkembang saat ini didapatkan dari pemeriksaan radiograf, dan berdampak pada perkembangan klasifikasi impaksi gigi kaninus rahang atas. Posisi dan bentuk impaksi gigi kaninus sejak lama telah digunakan sebagai parameter perencanaan tindakan odontomy. Klasifikasi impaksi gigi kaninus rahang atas yang pertama diawali oleh Archer. ${ }^{17}$ Kelebihan klasifikasi Archer adalah sangat sederhana karena diklasifikasikan berdasarkan posisi. Kekurangan klasifikasi menurut
Archer masih terlalu luas dan belum spesifik dalam memprediksi kesulitan perawatan impaksi gigi kaninus rahang atas.

Yammamato mengklasifikasikan impaksi caninus rahang atas berdasarkan karakteristik orientasi long axis gigi kaninus rahang atas terhadap bidang oklusal, yaitu Tipe I gigi akan erupsi dan terletak pada bagian labial dengan letak lebih rendah, jika ruang yang tersedia cukup maka akan terjadi erupsi secara alami. Pada tipe II jarang ditemukan rotasi gigi, tetapi sering ditemukan resorpsi akar gigi incisivus lateralis. Pada tipe III impaksi gigi kaninus bertepatan dengan pembentukan akar gigi premolar sehingga akar premolar melengkung. Pada tipe IV impaksi gigi kaninus sering ditemukan horizontal, dengan mahkota berada di mesial. Pada tipe $V$ impaksi gig kaninus terletak pada anterior dari dinding bawah sinus maksilaris dengan mahkota berada di distal. Pada tipe VI impaksi gigi kaninus terletak di dinding anterior sinus maksilaris dengan mahkota mengarah ke sudut medial mata dan terletak di dalam rongga hidung. Pada tipe VII impaksi labiopalatal atau impaksi yang terletak secara abnormal relatif jarang terjadi. ${ }^{20,21}$

Kelebihan dari sistem klasifikasi Yamamato adalah dapat diaplikasikan dengan mudah untuk melakukan rencana perawatan melalui pengamatan radiograf panoramik (2D). Kekurangan dari klasifikasi menurut Yamamato adalah tidak dapat mempertimbangkan rotasi gigi.

Ghoneima dalam penelitiannya menggunakan radiograf $\mathrm{CBCT}$ (3D) untuk memastikan keakuratan lokasi impaksi gigi kaninus rahang atas dan mengevaluasi resorpsi gigi incisivus lateralis. Ghoneima menyatakan klasifikasi impaksi gigi kaninus rahang atas berdasarkan posisi dan lokasi menjadi sepuluh kelompok. Hasil penelitian Ghoneima melaporkan bahwa tipe B yaitu gigi kaninus berada dalam posisi vertikal, terletak di posterior gigi incisivus lateralis dapat menyebabkan resorpsi akar gigi incisivus lateralis dan diikuti oleh tipe A dan C yaitu impaksi gigi kaninus mesioangular, terletak di posterior gigi incisivus sentralis dan mengakibatkan resorpsi akar gig incisivus sentralis. Tipe I dan tipe J paling langka terjadi. Klasifikasi impaksi gigi kaninus rahang atas menurut Ghoneima dapat digunakan sebagai dasar untuk pengembangan pengukuran dan parameter tertentu untuk setiap posisi dari impaksi gigi kaninus rahang atas sehingga dapat membantu dalam mendapatkan keputusan perencanaan perawatan yang tepat. ${ }^{9}$ Kelebihan dari klasifikasi Ghoneima adalah dapat melihat keterlibatan lebih dari dua gigi yang berdekatan pada daerah yang sama, dapat mempertimbangkan adanya rotasi gigi,dapat melihat hubungan impaksi gigi kaninus dengan sinus maksilaris dan septum nasalis. Kekurangan dari klasifikasi Ghoneima adalah tidak dapat menentukan kesulitan perawatan impaksi gigi kaninus rahang atas karena klasifikasi ini hanya dilakukan melalui pengamatan visual tanpa dilakukan skoring.

Kau dalam penelitiannya menyatakan radiograf konvesional memiliki keterbatasan dalam visualisasi 
impaksi gigi kaninus. Data volumetrik dari $\mathrm{CBCT}$ memberikan rekonstruksi multiplanar 3D yang bermanfaat untuk penilaian gigi impaksi. CBCT dapat digunakan untuk mengidentifikasi dan menentukan posisi impaksi gigi kaninus secara akurat. Indeks KPG adalah sistem klasifikasi 3-D pertama untuk klasifikasi impaksi gigi kaninus rahang atas. Klasifikasi impaksi gigi kaninus berdasarkan indeks KPG telah dikembangkan dalam upaya untuk membakukan diagnosis dan memprediksi kesulitan perawatan. ${ }^{14,15,16,19}$

Klasifikasi impaksi gigi kaninus rahang atas berdasarkan indeks KPG melalui radiograf CBCT lebih reliabel dan akurat untuk digunakan dalam menentukan rencana perawatan dan memprediks faktor resiko dari tindakan odontomy karena dilakukan berdasarkan jumlah dari semua skor $X$ skor $Y$, dan skor Z. Interval skor 0-9 termasuk dalam kategori mudah, skor 10-14 moderat, skor 15-19 sulit, skor di atas 20 sangat sulit. Metode indeks KPG membantu mengarahkan pada sistem klasifikasi impaksi gigi kaninus yang tepat sehingga dapat membantu dokter memperkirakan kesulitan perawatan impaksi gigi kaninus dengan cepat dan tepat. Kelebihan dari indeks KPG adalah adanya skoring melalui pengamatan sumbu $X$, sumbu $Y$, dan sumbu Z. Kekurangan dari indeks KPG adalah sangat rumit karena menggunakan skala seperti grid yang dibuat dari tiga tampilan radiograf berbeda yaitu sumbu $X$, sumbu $Y$, dan sumbu Z. ${ }^{14,15,16}$

Dalessandri dalam penelitiannya menyebutkan bahwa klasifikasi menurut Yamamato dan Ghoneima dapat digunakan, tetapi bukan instrumen yang reliabel dalam memprediksi tingkat kesulitan odontomy. Tingkat kesulitan odontomy dapat dengan mudah dinilai dengan menggunakan indeks KPG melalui radiograf CBCT. ${ }^{5,6}$

Klasifikasi impaksi gigi kaninus rahang atas berdasarkan Archer, Yamamato, Ghoneima, dan indeks KPG dapat digunakan sebagai panduan dalam melakukan diagnosa awal dan penentuan rencana perawatan, akan tetapi klasifikasi Archer dan Yamamato tidak dapat digunakan dalam memprediksi tingkat kesulitan perawatan karena keterbatasan dalam pengamatan radiograf yang diakibatkan adanya superimposed dan distorsi sehingga dapat mengakibatkan kesalahan dalam penafsiran posisi dan lokasi impaksi gigi kaninus dan hubungannya dengan jaringan di sekitar gigi.

\section{SIMPULAN}

Studi pustaka pada artikel ini memberikan petunjuk berupa klasifikasi impaksi gigi kaninus rahang atas telah dikembangkan berdasarkan pengamatan radiograf panoramik (2D) dan CBCT (3D), sehingga dihasilkan sebuah klasifikasi impaksi gigi caninus rahang atas yang lengkap mencakup aspek posisi, lokasi, orientasi long aksis gigi dan faktor resiko. Radiograf CBCT lebih reliabel dan akurat untuk digunakan dalam menentukan rencana perawatan dan memprediksi faktor resiko dari tindakan odontomy dibandingkan dengan radiograf panoramik (2D) akibat adanya superimposisi dan kesalahan proyeksi distorsi.

\section{DAFTAR PUSTAKA}

1. Alassiry A. Radiographic assessment of the prevalence, pattern and position of maxillary canine impaction in Najran (Saudi Arabia) population using orthopantomograms - A cross-sectional,retrospective study. Saudi Dental Journal 2020; 32 : 155-9.

2. Al-Zoubi, H, Alharbi AA, Ferguson, DJ, Zafar MS. Frequency of impacted teeth and categorization of impacted canines: retrospective radiographic study using orthopantomograms. Eur. J. Dent $2017 ; 11$ : 117-121.

3. Alqerban A, Jacobs R, Fieuws S, Willem G. Comparison of two cone beam computed tomographic systems versus panoramic imaging for localization of impacted maxillary canines and detection of root resorption. The European Journal of Orthodontics 2011 ; 33(1) : 93-102.

4. Becker A, Chaushu S, Casap-Caspi N. Cone-beam computed tomography and the orthosurgical management of impacted teeth. Journal of the American Dental Association $2010 ; 141$

5. Dalessandri D, Migliorati M, Rubiano R, Visconti L, Contardo L, Di Lenarda R, et al. Reliability of a novel CBCT-based 3D classification system for maxillary canine impactions in orthodontics: the KPG index. Scientific World Journal 2013;2013:921234.

6. Dalessandri D, Migliorati M, Visconti L, Contardo L, Kau CH, Martin C. KPG index versus OPG measurements: comparison between $3 \mathrm{D}$ and $2 \mathrm{D}$ methods in predictin treatment duration and difficulty level for patients with impacted maxillary canines. BioMed Res Int 2014;2014:537620.

7. Goyal B, Munjal S, Singh S, Natt SA, Singh H. Impacted canine : An arduos task. Journal of Applied Dental and Medical Science 2018; 4:136-41.

8. Grisar K, Piccart F, Rimawi A, Basso I, Politis C, Jacobs R. Three-dimensional position of impacted maxillary canines: Prevalence, associated pathology and introduction to a new classification system. Clin Exp Dent Res $2019 ; 5: 19-25$.

9. Ghoneima a, kanomi R, Deguchi T. Position and Distribution of Maxillary Displaced Canine in a Japanese Population: a Retrospective Study of 287 CBCT Scans. Anat Physiol 2014 $4: 1-5$.

10. Haralur SB, Al Shahrani, S Alqahtani, F Nusair, Y Alshammari, O Alshenqety. Incidence of impacted maxillary canine teeth in Saudi Arabian subpopulation at central Saudi Arabian region. Ann Trop Med $2017 ; 10: 558-562$.

11. Hussein MA, Watted $\mathrm{N}$, Hussien $\mathrm{E}$, Maxillary Impacted canines;clinical review. Int J dent and Med Science Reserch 2017 ; 1(6) :10-26

12. Hou, R. Investigation of impacted permanent teeth except the third molar in Chinese patients through an X-ray study. J. Oral Maxillofac Surg $2010 ; 68: 762-767$.

13. J Brown, R Jacobs, E Levring Jaghagen . Basic training requirements for the use of dental CBCT by dentists: a position paper prepared by the European Academy of DentoMaxilloFacial Radiology. Dentomaxillofacial Radiology $2014 ; 43$ (1).

14. Jung $\mathrm{Y} \mathrm{H}$, Liang $\mathrm{H}$, Benson BW, Flint $\mathrm{DJ}$, Cho BH. The assessment of impacted maxillary canine position with panoramic radiography and cone beam CT. Dentomaxillofac Radiol $2012 ; 41: 356-360$

15. Kau CH, Lee JJ, Souccar NM, The validation of a novel index assessing canine impactions. Eur J Dent 2013;7(4):399-404

16. Kau $\mathrm{CH}$, Migliorati M, Visconti L, Contardo L, Martin C, KPG index versus OPG measurement : a comparison between 3D and $2 \mathrm{D}$ methods in predicting treatment duration and difficulty level for patients with impacted maxillary canines. BMRI $2014 ; 1-7$.

17. Kau CH, Pan P, Gallerano RL, English JD, A novel 3D classification system for canine impactions--the KPG index. Int J Med Robot Comput Assist Surg MRCAS 2009;5(3):291-6.

18. Konda P, Ahmed MU, Ali SM, Konda A. Impacted Maxillary Canine -At a Glance.IJCD 2011; 2(6): 65-70.

19. Kim $\mathrm{Y}$, Hyun $\mathrm{H}-\mathrm{K}$, Jang $\mathrm{K}-\mathrm{T}$. Interrelationship between the position of impacted maxillary canines and the morphology of the maxilla. Am J Orthod Dentofac Orthop Off Publ Am Assoc Orthod Its Const Soc Am Board Orthod 2012;141 (5):556-62 
20. Lai CS, Bornstein MM, MMock L, Heurbeger BM. Impacted Maxillary canines and root resorptions of neighbouring teeth : a radiographicanalysis using cone-beam computed. European Journal of Orthodontics $2013 ; 35: 529-38$.

21. Lindauer SJ, Rubbenstein LK, Hang WM, Andersen $C$ Isachoon RJ. Canine impaction identified early with panoramic radiographs. JADA $2012 ; 123 ; 92-7$

22. Yamamato G, Ohta $Y$, Tsuda $Y$, Tanka A, Nishikawa $M$, Inoda $\mathrm{H}$. A new classification of impacted canines and second premolars using ortopanatomography. Asian J Oral Maxillofac Surg 2003; 15:31-7. 